\title{
Peningkatan Proses Pembelajaran Tematik Terpadu dengan Menggunakan Model Discovery Learning di Kelas IV Sekolah Dasar
}

\author{
Yosneni watipah \\ Program Studi PG-SD Fakultas IImu Pendidikan \\ Universitas Negeri Padang \\ Email : yosneniwatipah07@gmail.com
}

\begin{abstract}
Abstrak
Penelitian ini bertujuan untuk mendeskripsikan peningkatan proses belajar siswa dalam pembelajaran tematik terpadu dengan menggunakan model Discovery Learning dengan tema kayanya negeriku di kelas IV SD Negeri 07 Teladan Kec. Guguk Panjang Kota Bukittinggi. Pendekatan yang digunakan dalam Penelitian Tindakan Kelas ini adalah pendekatan kualitatif dan kuantitatif yang dilaksanakan dalam dua siklus. Subjek penelitian ini adalah guru dan 36 orang siswa kelas IV SDN 07 Teladan Kec. Guguk Panjang Kota Bukittinggi. Hasil penelitian menunjukkan bahwa pada siklus I penilaian RPP rata-rata $77,75 \%$ (baik) ,Aspek guru rata-ratanya 79,65\% (baik), Aspek siswa rata-ratanya $81,15 \%$ (baik), Penilaian terhadap siswa dari aspek sikap, pengetahuan, dan keterampilan dengan rata-rata 74,80 dengan konversi nilai 3,24 ( $\mathrm{B}+$ ). Pada siklus II penilaian RPP rata-ratanya 94,4\% (sangat baik), Aspek guru rata-ratanya $93,75 \%$ (sangat baik), Aspek siswa rata-ratanya 93,75\% (sangat baik), Penilaian terhadap siswa dari aspek sikap, pengetahuan, dan keterampilan rata-ratanya 82,18 dengan konversi nilai 3,46 (B+). Dari hasil penelitian dapat disimpulkan bahwa dengan menggunakan model Discovery Learning dapat meningkatkan proses pembelajaran tematik terpadu di kelas IV SD Negeri 07 Teladan Kec. Guguk Panjang.
\end{abstract}

Kata Kunci: Proses Pembelajaran, Tematik Terpadu, Model Discovery Learning

\section{PENDAHULUAN}

Pembelajaran tematik terpadu merupakan pembelajaran yang dirancang berdasarkan tema-tema tertentu dan ditinjau dari berbagai mata pelajaran. Dalam pembelajaran tematik terpadu tema merupakan pemersatu kegiatan pembelajaran yang mengaitkan beberapa mata pelajaran guna memberikan pengalaman langsung kepada siswa. Pembelajaran tematik memiliki ciri berpusat pada siswa (student centre). Siswa didorong untuk melakukan, menemukan, dan mengalami secara 
kontekstual dengan menggunakan sumber daya yang dimiliki. Pembelajaran akan lebih bermakna karena siswa langsung melakukan (doing) dan mengalami (experience) sendiri suatu aktivitas.

Sesuai dengan pendapat Majid (2014: 80) bahwa, "Pembelajaran tematik terpadu adalah pembelajaran yang terpadu yang menggunakan tema untuk mengaitkan beberapa mata pelajaran sehingga dapat memberikan pengalaman yang bermakna kepada murid".

Di dalam penyajian materi pembelajaran guru harus mampu menyajikan materi dari berbagai mata pelajaran dengan utuh dan tidak terpisah-pisah dalam sebuah tema yang telah ditentukan. Dengan penyajian materi secara terpadu, siswa akan lebih mudah untuk memahami materi pembelajaran. Hal ini telah dijelaskan dalam Kemendikbud (2014:16) bahwa "anak pada usia sekolah dasar berada pada tahap operasi kongkret". Dengan demikian konsep pembelajaran bisa tertanam dengan baik pemilihan materi yang disajikan harus berkaitan dengan kehidupan sehari-hari siswa dan disesuaikan dengan lingkungan siswa sehingga siswa akan lebih mudah mengerti dan proses belajar mengajar akan lebih menyenangkan dan dapat diaplikasikan oleh siswa di dalam lingkungannya. Keuntungan pendekatan tematik terpadu dalam pembelajaran yaitu dapat memberikan pembelajaran yang bermakna bagi peserta didik dan menciptakan suasana belajar yang menyenangkan.

Berdasarkan observasi yang dilakukan peneliti di SDN 07 Teladan Kec. Guguk Panjang Kota Bukittinggi pada hari Rabu tanggal 14 Desember 2017, peneliti menemukan beberapa masalah dalam pembelajaran baik dari aspek perencaaan, aspek guru maupun dari aspek siswa yang tidak sesuai dengan kriteria proses pembelajaran efisien dan efektif pada kurikulum 2013.

Dari aspek perencanaan pembelajaran, guru hanya menyalin apa yang ada pada buku guru, kurang mengembangkan indikator dari kompetensi dasar yang terkait serta minimnya guru dalam mengembangkan model pembelajaran yang akan digunakan sehingga pada pelaksanaannya tujuan pembelajaran yang akan dicapai siswa belum tercapai secara optimal.

Dari aspek pelaksanaan guru yaitu (1) belum maksimal memberikan ransangan atau pembangkit pengetahuan siswa dalam memulai kegiatan pembelajaran, (2) bimbingan guru terhadap siswa untuk menyelidiki masalah yang terkait dengan pembelajaran kurang maksimal, sehingga proses pembelajaran yang berpusat kepada siswa (student centered) kurang terlihat, (3) pembelajaran yang dilakukan guru belum memberikan pembuktian atau pemeriksaan secara maksimal terhadap kecocokan materi pembelajaran dengan kehidupan sehari-hari, dan (4) 
Guru belum sepenuhnya membimbing siswa membuat kesimpulan yang tepat dan jelas.

Kekurangan yang dialami guru tersebut mempengaruhi kegiatan belajar siswa, yaitu (1) siswa kurang maksimal memperoleh informasi berdasarkan kehidupan nyatanya,(2) siswa kurang optimal dalam menyelidiki pembelajaran dan mengemukakan gagasan ataupun pengetahuan yang diketahuinya menyebabkan pembelajaran tidak berpusat pada siswa, dan (3) siswa belum maksimal dalam membuat kesimpulan tentang apa yang telah dipelajari serta kurangnya motivasi siswa untuk belajar.

Permasalahan yang dihadapi saat proses pembelajaran berlangsung berakibat pada hasil belajar yang rendah. Terlihat dari ketercapaian nilai rata-rata, sebagian besar siswa tidak memenuhi kriteria ketuntasan minimal (KKM). Hanya beberapa orang siswa yang mampu mencapai KKM yang diberlakukan di SD Negeri 07 Teladan Kec. Guguk Panjang Kota Bukittinggi. Dari 36 siswa di kelas IV, yang memenuhi standar KKM hanya 15 orang siswa saja sedangkan 21 siswa lainnya belum mencapai standar KKM. Jika permasalahan ini tidak diatasi maka akan berdampak buruk bagi proses pembelajaran dan keberhasilan siswa selanjutnya.

Untuk mengatasi permasalahan di atas guru harus mampu memilih model pembelajaran yang tepat. Salah satu model pembelajaran yang tepat dalam pembelajaran tematik terpadu di sekolah dasar menurut penulis adalah model Discovery Learning. Menurut Hanafiah, dkk (dalam Faisal, 2014:102) Discovery Learning adalah suatu rangkaian kegiatan pembelajaran yang melibatkan secara maksimal seluruh kemampuan siswa untuk mencari dan menyelidiki secara sistematis, kritis, dan logis sehingga mereka dapat menemukan sendiri pengetahuan, sikap dan keterampilan sebagai wujud adanya perubahan perilaku.

Model pembelajaran ini sangat cocok digunakan pada pembelaaran tematik terpadu, karena model pengajaran ini siswa didorong untuk menemukan sendiri pengetahuannya, melalui pengumpulan data, pengolahan data, dan menarik kesimpulan sehingga pembelajaran pun akan menarik dan menyenangkan bagi siswa serta output yang dihasilkan berupa pengetahuan bagi siswa pun akan bertahan lama untuk diingat siswa. Model Discovery Learning menempatkan guru hanya sebagai stimulator, motivator dan fasilitator dalam pembelajaran, tentu hal ini sesuai dengan harapan kurikulum 2013 bahwa pembelajaran tidak lagi terpusat kepada guru.

Dengan menggunakan model Discovery Learning siswa diharapkan dapat berperan aktif dalam proses pembelajaran karena model ini merupakan model pembelajaran dengan melibatkan siswa dalam 
pemecahan suatu masalah sehingga siswa memperoleh pengalaman langsung dari proses menemukan konsep yang dipelajarinya.

Berdasarkan uraian diatas, maka tujuan dari penelitian ini adalah untuk mendeskripsikan peningkatan proses pembelajaran tematik terpadu dengan menggunakan model Discovery Learning pada siswa kelas IV SD Negeri 07 Teladan Kec. Guguk Panjang Kota Bukittinggi

\section{METODE PENELITIAN}

Penelitian ini menggunakan jenis penelitian tindakan kelas (PTK) dengan menggunakan analisis data kualitatif dan kuantitatif dengan subjek penelitian siswa kelas IV SDN SD Negeri 07 Teladan Kec. Guguk Panjang Kota Bukittinggi pada semester II Tahun Ajaran 2016/2017 dengan jumlah siswa 36 orang. Penelitian ini menggunakan alur penelitian model Kemmis \& Mc Taggart, dkk (dalam Hamzah dkk, 2012:88) "Secara garis besar terdapat empat langkah yang dilalui, yaitu (1) perencanaan, (2) pelaksanaan, (3) pengamatan, dan (4) refleksi ".

Data penelitian berupa hasil pengamatan dan tes, dari setiap tindakan perbaikan pada pembelajaran tematik terpadu dengan model Discovery Learning pada siswa kelas IV SD Negeri 07 Teladan Kec. Guguk Panjang Kota Bukittinggi. Data tersebut tentang hal-hal yang berkaitan dengan perencanaan, pelaksanaan, dan hasil belajar. Sumber data penelitian adalah proses pembelajaran tematik terpadu dengan menggunakan model Discovery Learning di kelas IV SDN SD Negeri 07 Teladan Kec. Guguk Panjang Kota Bukittinggi yang meliputi perencanaan pembelajaran, pelaksanaan pembelajaran, kegiatan evaluasi, perilaku guru dan siswa sewaktu proses pembelajaran. Data diperleh dari subjek terteliti yakni, guru dan siswa kelas IV SD Negeri 07 Teladan Kec. Guguk Panjang Kota Bukittinggi

Teknik pengumpulan data dilakukan secara observasi, tes dan nontes. Observasi dilakukan untuk mengamati latar kelas berlangsungnya pembelajaran tematik terpadu dengan menggunakan model Discovery Learning. Dengan berpedoman pada lembaran observasi, peneliti mengamati apa yang terjadi selama proses pembelajaran. Tes dan nontes digunakan untuk memperkuat data observasi yang terjadi dalam kelas terutama pada butir penguasaan materi pembelajaran dari unsur siswa.

Instrument penelitiandikumpulkan berdasarkan observasi terhadap RPP, pelaksanaan tindakan pembelajaran dari aspek guru maupun siswa, dan tes penilaian proses dan hasil belajar. Data dikumpulkan selama 3 hari dalam tiga minggu dengan cara peneliti menjadi guru pengganti pada proses pembelajaran tematik terpadu dengan menggunakan model Discovery Learning di kelas IV SD Negeri 07 Teladan Kec. Guguk Panjang Kota Bukittinggi. 


\section{HASIL DAN PEMBAHASAN}

\section{Siklus I}

\section{Perencanaan}

Perencanaan penelitian tergambar dalam bentuk Rencana Pelaksanaan Pembelajaran (RPP). Perencanaan yang dilakukan berdasarkan program akademik semester II sesuai dengan waktu penelitian yang dilaksanakan.

Rencana Pelaksanaan Pembelajaran yang dilaksanakan terdiri dari Kompetensi Inti (KI), Kompetensi Dasar (KD), indikator, tujuan pembelajaran, materi pembelajaran, pendekatan dan metode, media dan sumber belajar, kegiatan pembelajaran, serta penilaian.

Penilaian terhadap RPP dilaksanakan melalui lembar penilaian RPP dengan aspek penilaian yang terdiri dari: (a) Identitas mata pelajaran, (b) Perumusan indikator, (c) Perumusan tujuan pembelajaran, (d) Pemilihan materi, (e) pemilihan sumber belajar, (f) Pemilihan media belajar, (g) Model pembelajaran, (h) Skenario pembelajaran, dan (i) Rancangan penilaian autentik.

\section{Pelaksanaan}

Berdasarkan RPP yang disusun, pembelajaran pada penelitian melalui tiga langkah, yaitu kegiatan awal, kegiatan inti, dan kegiatan akhir dengan menggunakan model Discovery Learning.Menurut Syah (dalam Kemendikbud, 2014:32-33) yaitu (1) Stimulation (stimulasi/ pemberian rangsangan), (2) Problem statement (pernyataan/ identifikasi masalah), (3) Data collection (pengumpulan data), (4) Data processing (pengolahan data), (5) verification (pembuktian), dan (6) Generalization (menarik kesimpulan).

Pelaksanaan pembelajaran tematik terpadu menggunakan model Discovery Learning dikelas IV SDN 07 Teladan siklus I pertemuan 1 dilaksanakan pada hari Selasa, 25 April 2017. Siswa yang hadir pada siklus I pertemuan 1 adalah 36 orang, pembelajaran berlangsung selama 280 menit. Tema yang diajarkan pada siklus I pertemuan 1 adalah tema 9 "Kayanya Negeriku", subtema 1 "Kekayaan Sumber Energi di Indonesia", pembelajaran satu.

Siklus I pertemuan 2 dilaksanakan pada hari Kamis, 2 Mei 2017. Siswa yang hadir pada siklus I pertemuan 2 adalah 36 orang, pembelajaran berlangsung selama 280 menit. Tema yang diajarkan pada siklus I pertemuan 2 adalah tema 9 "Kayanya Negeriku", subtema 2 "Pemanfaatan Kekayaan Alam di Indonesia", pembelajaran satu.

Berdasarkan susunan rencana pelaksanaan pembelajaran yang telah disusun sebelumnya, pelaksanaan pembelajaran pada siklus I 
mengikuti langkah-langkah pembelajaran yang terdiri dari tiga tahap yaitu kegiatan pendahuluan, kegiatan inti, dan kegiatan penutup.

\section{Pengamatan}

Pengamatan dilakukan setiap siklus dan pertemuan. Hasil yang diperoleh berdasarkan observasi terhadap RPP pada siklus I diperoleh rata-rata $77,75 \%$ dengan kualifikasi cukup (C). Berdasarkan hasil observasi yang dilakukan terhadap tindakan guru dalam pembelajaran siklus I diperoleh rata-rata 79,65\% dengan kualifikasi baik (B).Sedangkan hasil observasi pada tindakansiswa sikslu I diperoleh rata-rata 81,15\% dengan kualifikasi baik (B).

Hasil belajar siswa dilihat dari hasil evaluasi yang dilakukan. Dari hasil belajar yang diperoleh dapat diuraikan: (1) Aspek sikap, keberhasilan siswa dari aspek sikap dilihat selama proses pembelajaran berlangsung selama siklus I diperoleh rata-rata 74,08 (2) Aspek pengetahuan, diperoleh rata-rata 75,69 (3) Aspek keterampilan dipeorleh rata-rata 74,62. Persentase ketuntasan siswa pada siklus I pertemuan 1 yaitu 58,3\% meningkat menjadi $75 \%$ pada pertemuan 2 .

\section{Siklus II}

\section{Perencanaan}

Materi pembelajaran dilaksanakan pada siklus II adalah pembelajaran 1 pada tema "Kayanya Negeriku" dengan sub tema "Pelestarian Sumber Daya Alam Indonesia". Pembelajaran 1dilaksanakan dalam 1 kali pertemuan dengan alokasi waktu 8 x 35 menit. Penyusunan perencanaan tindakan dilakukan berdasarkan Kurikulum 2013 dan dituangkan dalam seperangkat Rencana Pelaksanaan Pembelajaran (RPP). Kompetensi Inti (KI) yang peneliti ambil dari buku kurikulum 2013 adalah 1) Menerima dan menjalankan ajaran agama yang dianutnya, 2) Memiliki perilaku jujur, disiplin, tanggung jawab, santun, peduli, dan percaya diri dalam berinteraksi dengan keluarga, teman, guru, dan tetangganya 3) Memahami pengetahuan faktual dengan cara mengamati (mendengar, melihat, membaca) dan menanya berdasarkan rasa ingin tahu tentang dirinya, makhluk ciptaan Tuhan dan kegiatannya, dan bendabenda yang dijumpainya di rumah, sekolah, dan tempat bermain, 4) Menyajikan pengetahuan faktual dalam bahasa yang jelas, sistematis, dan logis, dalam karya yang estetis, dalam gerakan yang mencerminkan anak sehat, dan dalam tindakan yang mencerminkan perilaku anak beriman dan berakhlak mulia.

Pembelajaran tematik terpadu pada kurikulum 2013 memiliki beberapa kompetensi dasar di masing-masing muatan pembelajaran yang terkandung di dalamnya. Kompetensi dasar yang akan dicapai dalam pelaksanaan penelitian muatan pembelajaran IPA adalah 1)Bertambah 
keimanannya dengan menyadari hubungan keteraturan dan kompleksitas alam dan jagad raya terhadap kebesaran Tuhan yang menciptakannya, serta mewujudkannya dalam pengamalan ajaran agama yang dianutnya, 2)Menunjukkan perilaku ilmiah (memiliki rasa ingin tahu; obyektif; jujur; teliti; cermat; tekun; hati-hati; bertanggung jawab; terbuka; dan peduli lingkungan) dalam aktivitas sehari-hari sebagai wujud implementasi sikap dalam melakukan inkuiri ilmiah dan berdiskusi, 3) Mengidentifikasi berbagai sumber energi, perubahan bentuk energi, dan sumber energi alternatif (angin, air, matahari, panas bumi, bahan bakar organik, dan nuklir) dalam kehidupan sehari-hari, 4) Menyajikan laporan hasil pengamatan dan penelusuran informasi tentang berbagai perubahan bentuk energi. Kompetensi Dasar yang akan dicapai pada pembelajaran Bahasa Indonesia adalah 1)Meresapi keagungan Tuhan Yang Maha Esa atas penciptaan makhluk hidup, hidup sehat, benda dan sifatnya, energi dan perubahan, bumi dan alam semesta, 2) Memiliki kepedulian terhadap gaya, gerak, energi panas, bunyi, cahaya, dan energi alternatif melalui pemanfaatan bahasa Indonesia, 3) Menggali informasi dari seorang tokoh melalui wawancara menggunakan daftar pertanyaan, 4) Melaporkan hasil wawancara menggunakan kosakata baku dan kalimat efektif dalam bentuk teks tulis. Kompetensi dasar yang akan dicapai pada pembelajaran IPS adalah 1) Menerima karunia Tuhan Yang Maha Esa yang telah menciptakan manusia dan lingkungannya. 2) Menunjukkan perilaku santun, toleran dan peduli dalam melakukan interaksi sosial dengan lingkungan dan teman sebaya. 3) Mengidentifikasi karakteristik ruang dan pemanfaatan sumber daya alam untuk kesejahteraan masyarakat dari tingkat kota/kabupaten sampai tingkat provinsi, 4) Menyajikan hasil identifikasi karakteristik ruang dan pemanfaatan sumber daya alam untuk kesejahteraan masyarakat dari tingkat kota/ kabupaten sampai tingkat provinsi.

Indikator pembelajaran IPA pada penelitian siklus II adalah 1) Menyebutkan sumber-sumber energi alternative, 2) Menjelaskan manfaat sumber-sumber energi alternative, dan 3) Melaporkan contoh energi alternatif dan kegunaannya dalam kehidupan sehari-hari. Indikator pembelajaran IPS adalah 1) Menyebutkan pelestarian sumber daya alam di kehidupan sehari-hari, 2) Melaporkan hasil identifikasi pelestarian sumber daya alam. Indikator pembelajaran Bahasa Indonesia adalah 1) Menemukan kalimat utama setiap paragraf, 2) Menemukan informasi tentang lingkungan dari seorang narasumber melalui wawancara menggunakan daftar pertanyaan, 3) Menulis laporan hasil wawancara menggunakan kosakata baku dan kalimat efektif dalam bentuk teks tulis. 4) Melaporkan hasil wawancara. 


\section{Pelaksanaan}

Berdasarkan RPP yang disusun, pembelajaran pada penelitian melalui tiga langkah, yaitu kegiatan awal, kegiatan inti, dan kegiatan akhir dengan menggunakan model Discovery Learning.Menurut Syah (dalam Kemendikbud, 2014:32-33) yaitu (1) Stimulation (stimulasi/ pemberian rangsangan), (2) Problem statement (pernyataan/ identifikasi masalah), (3) Data collection (pengumpulan data), (4) Data processing (pengolahan data), (5) verification (pembuktian), dan (6) Generalization (menarik kesimpulan).

Pelaksanaan pembelajaran tematik terpadu menggunakan model Discovery Learning dikelas IV SDN 07 Teladan Bukittinggi siklus II dilaksanakan pada hari Selasa, 9 Mei 2017. Siswa yang hadir pada siklus II adalah 36 orang, pembelajaran berlangsung selama 280 menit. Tema yang diajarkan pada siklus II adalah tema 9 "Kayanya Negeriku", subtema 3 "Pelestarian Sumber Daya Alam Indonesia", pembelajaran 1.

Berdasarkan susunan rencana pelaksanaan pembelajaran yang telah disusun sebelumnya, pelaksanaan pembelajaran pada siklus II mengikuti langkah-langkah pembelajaran yang terdiri dari tiga tahap yaitu kegiatan pendahuluan, kegiatan inti, dan kegiatan penutup.

\section{Pengamatan}

Pengamatan dilakukan setiap siklus dan pertemuan. Hasil yang diperoleh berdasarkan hasil observasi terhadap RPP yaitu dengan skor 34 dari skor maksimal 36 sehingga diperoleh persentase 94,4\%dengan kualifikasi sangat baik. Berdasarkan hasil observasi yang dilakukan terhadap tindakan guru dalam pembelajaran siklus II jumlah skor yang diperoleh 30 dari skor maksimal 32 sehingga diperoleh persentase $93,75 \%$ dengan kualifikasi sangat baik. Sedangkan hasil observasi pada tindakan siswa skor yang diperoleh 30 dari skor maksimal 32 sehingga diperoleh persentase $93,75 \%$ dengan kualifikasi sangat baik.

Hasil belajar siswa dilihat dari hasil evaluasi yang dilakukan. Dari hasil belajar yang diperoleh dapat diuraikan: (1) Aspek sikap, keberhasilan siswa dari aspek sikap dilihat selama proses pembelajaran berlangsung selama siklus II dengan rata-rata 83,6, (2) Aspek pengetahuan, dengan rata-rata 82,56, (3) Aspek keterampilan dengan rata-rata 80,90. Persentase ketuntasan siswa pada siklus II yaitu 88,9\%. Untuk lebih jelasnya, peningkatan hasil penelitian siklus I dan siklus II dapat dilihat pada grafik di bawah ini. 


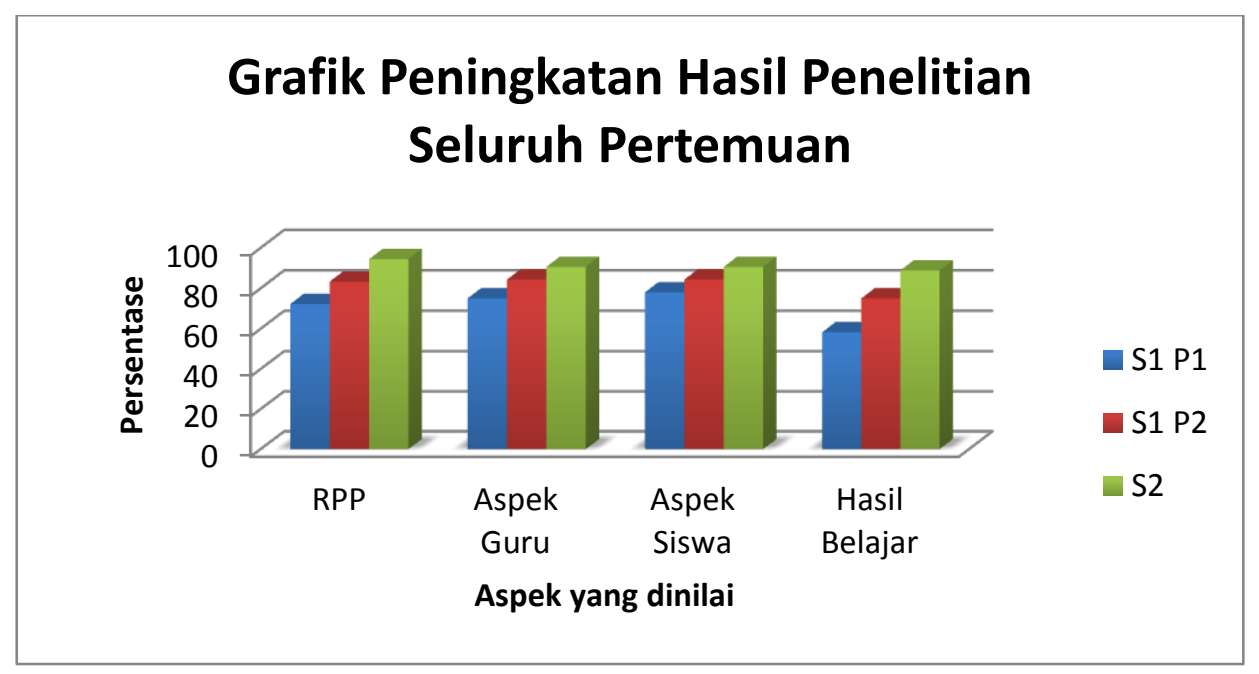

\section{PEMBAHASAN}

\section{Siklus 1}

\section{Pelaksanaan}

Pada pelaksanaan pembelajaran tematik terpadu untuk meningkatkan proses pembelajaran menggunakan model Discovery Learning siklus I meliputi: (1) pendahuluan; (2) inti dan (3) penutup. Berdasarkan data yang telah dipaparkan pada pelaksanaan dan pengamatan tindakan terhadap pelaksanaan pembelajaran tematik terpadu untuk meningkatkan proses pembelajaran dengan menggunakan model Discovery Learning siklus I, pembelajaran yang telah dilakukan telah sesuai dengan langkah-langkah pelaksanaan model pembelajaran yang dikemukakan oleh Syah (dalam Kemendikbud, 2014:32-33) menjelaskan langkah-langkah menggunakan model Discovery Learning adalah: (1) Stimulation/pemberian rangsangan; (2) Problem Statement/ identifikasi masalah; (3) Data Collection/ pengumpulan data; (4) Data Processing/pengolahan data; (5) Verification/ pembuktian dan (6) Generalization/kesimpulan.

Berdasarkan lembar pengamatan aktivitas guru dalam pembelajaran tematik terpadu untuk meningkatkan proses pembelajaran beberapa tahap pembelajaran yang belum terlaksana dengan baik. Pada pendahuluan, pada saat menyampaikan tujuan pembelajaran, guru belum memberikan motivasi agar siswa belajar dengan rajin. Saat pelaksanaan pembelajaran guru kurang memberikan motivasi kepada siswa maupun penghargaan kepada siswa saat menyampaikan pendapatnya. Akibatnya siswa menjadi kurang bersemangat dalam pembelajaran dan tidak jarang siswa menjadi pasif. Sebagai motivator, guru harus senantiasa memberi motivasi kepada siswa. Sebagaimana pendapat Rusman (2011: 246) bahwa salah satu tugas guru dalam pelaksanaan model Discovery Learning adalah "Guru harus siap menjadi pembimbing sekaligus tutor 
bagi para siswa yang dapat memberikan motivasi, semangat, dan membantu dalam menguasai keterampilan pemecahan masalah."

Dalam proses pembelajaran, motivasi dan bimbingan sangatlah dibutuhkan terutama bagi siswa yang mengalami kesulitan. Dengan adanya motivasi dari guru, siswa akan lebih percaya diri dalam mengemukakan pendapatnya. Begitu juga dengan penghargaan. Penghargaan dapat dilakukan dengan hal yang sederhana seperti membenarkan pendapat siswa, memberikan pujian terhadap penampilan siswa, senyuman dan anggukan. Berdasarkan uraian di atas, seharusnya seorang guru bisa menjadi motivator dan fasilitator yang baik bagi siswa karena motivasi dan dorongan berkaitan erat dengan keberhasilan dalam pembelajaran. Pada tahap pelaksanaan rata-rata persentase keberhasilan aktivitas guru pada siklus I memperoleh 79,65\% dengan kualifikasi baik (B) dan aktivitas siswa memperoleh $81,15 \%$

\section{Penilaian}

Pencapaian hasil penilaian peningkatan proses pembelajaran pada pembelajaran tematik terpadu dengan menggunakan model Discovery Learning yang dilakukan guru meliputi tiga aspek yaitu aspek sikap, pengetahuan, dan keterampilan. Adapun hasil penilaian siswa pada aspek sikap diperoleh nilai rata-rata siswa, yaitu 74,08 dengan konversi nilai 3,22 (B). Penilaian aspek pengetahuan didapat nilai rata-rata siswa 75,69 dengan konversi nilai 3,27 (B+). Penilaian pada aspek keterampilan diperoleh nilai rata-rata siswa 74,62 dengan konversi nilai 3,24 (B+).

\section{Siklus II \\ Pelaksanaan}

Pada pelaksanaan, secara keseluruhan berbagai aspek dalam pelaksanaan pembelajaran sudah terlaksana dengan baik. Komponen yang telah berada pada kriteria sangat baik yaitu pada langkah pemberian rangsangan, identifikasi masalah, pengolahan data, dan menarik kesimpulan. Sedangkan indikator yang belum muncul yaitu guru belum meminta siswa membaca halhal apa saj yng akan dilakukan dan dinyatakan pada saat diskusi dan guru belum meminta siswa ituk menyatakan pendapatnya tentang setiap manusia berkewajiban untuk melestarikan lingkungan maupun sumber daya alam.

Hasil pengamatan aspek guru pada siklus II memperoleh skor 30 dari skor maksimal 32 dengan persentase 93,75\% dan berada pada kualifikasi sangat baik (SB). Pada aspek siswa memperoleh skor 30 dari skor maksimal 32 dengan persentase $93,75 \%$ dan berada pada kualifikasi sangat baik (SB). 


\section{Penilaian}

Peningkatan pada pelaksanaan pembelajaran juga berdampak pada hasil belajar yang meningkat. Penilaian siswa pada aspek sikap meningkat menjadi 83,6 dengan konversi nilai 3,51 (A). Penilaian aspek pengetahuaan siswa meningkat dengan rata-rata 82,56 dengan konversi nilai 3,48 $(\mathrm{B}+)$. Penilaian pada aspek keterampilan diperoleh nilai rata-rata siswa 80,90 dengan konversi nilai 3,44 $(\mathrm{B}+)$.

Berdasarkan paparan data hasil pengamatan perencanaan, pelaksnaan dan penilaian pembelajaran tematik terpadu yang peneliti uraikan di atas, hasil pembelajaran yang diperoleh siswa pada tindakan peningkatan proses pembelajaan tematik terpadu dengan model Discovery Learning siklus II berjalan jauh lebih baik daripada siklus I. Siswa yang sebelumnya belum mencapai standar ketuntasan maksimal, pada siklus II mampu mencapai standar dan bahkan beberapa siswa mampu melebihinya.

Menurut Mulyasa (2014:143) "dari segi hasil, proses pembelajaran dikatakan berhasil apabila terjadi perubahan perilaku yang positif pada diri peserta didik seluruhnya atau setidak-tidaknya sebagian besar (80\%)". Hal ini berarti jika hasil penilaian yang menonjolkan aspek sikap melebihi $80 \%$, lalu diperkuat dengan rata-rata hasil penilaian sikap, pengetahuan dan keterampilan yang telah melebihi kriteria ketuntasan minimal (KKM), maka dapat dikatakan berhasil. Jadi, dapat dikatakan bahwa dengan model Discovery Learning dapat meningkatkan proses pembelajaran tematik terpadu di kelas IV SD Negeri 07 Teladan Kec. Guguk Panjang Kota Bukittinggi.

\section{SIMPULAN}

Berdasarkan hasil penelitian dan pembahasan peneliti dapat disimpulkan bahwa (1) Perencanaan pembelajaran tematik terpadu di kelas IV SD dengan menggunakan model Discovery Learning dituangkan dalam bentuk rencana pelaksanaan pembelajaran yang komponen penyusunnya terdiri dari kompetensi inti, kompetensi dasar, indikator, tujuan pembelajaran, materi pembelajaran, kegiatan pembelajaran, model dan metode pembelajaran, sumber dan media, dan penilaian. Rencana pelaksanaan pembelajaran dirancang dengan langkah-langkah (a) Stimulation (b) Problem Statement, (c) Data Collection, (d) Data Processing, (e) Verification, dan (f) Generalization. Hasil penilaian perencanaan pelaksanaan pembelajaran siklus I rata-ratanya adalah $77,75 \%$ dengan kriteria cukup. Kemudian meningkat pada siklus II, yaitu $94,4 \%$ dengan kriteria sangat baik. (2) Pelaksanaan pembelajaran tematik terpadu dengan model Discovery Learning terdiri dari kegiatan pendahuluan, kegiatan inti, dan kegiatan penutup. Dalam pelaksanaan pembelajaran tematik terpadu dengan menggunakan model Discovery 
Learning dilakukan penilaian proses berdasarkan aspek guru dan siswa. Pelaksanaan pembelajaran tematik terpadu dengan menggunakan model Discovery Learning dilaksanakan dengan langkah-langkah: (a) Stimulation (b) Problem Statement, (c) Data Collection, (d) Data Processing, (e) Verification, dan (f) Generalization. Hasil pengamatan dari pelaksanaan pembelajaran tematik terpadu dengan menggunakan model Discovery Learning berdasarkan aktivitas guru pada siklus I menunjukkan bahwa pelaksanaan pembelajaran belum maksimal dengan persentase nilai ratarata yang diperoleh adalah $79,65 \%$ dengan kriteria baik. Pada siklus II terjadi peningkatan dengan persentase nilai $93,75 \%$ dengan kriteria sangat baik. Sedangkan pada aktivitas siswa persentase nilai yang diperoleh pada siklus I rata-ratanya adalah $81,15 \%$ dengan kriteria baik. Pada siklus II persentase nilai 93,75\% dengan kriteria sangat baik. Dari hal ini, terlihat bahwa ada peningkatan dari kegiatan mengajar guru dan aktivitas siswa pada tahap pelaksanaan mulai dari siklus I sampai siklus II. (3) Penilaian terhadap siswa dalam peningkatan proses pembelajaran tematik terpadu dengan menggunakan model Discovery Learning pada siklus I pertemuan 1 diperoleh persentase nilai rata-rata, yaitu 70,68 dengan konversi nilai $3,12(\mathrm{~B})$, pada siklus I pertemuan 2 meningkat menjadi 78,91 dengan konversi nilai $3,37(\mathrm{~B}+)$ dan pada siklus II meningkat lagi menjadi 82,18 dengan konversi nilai 3,46 ( $\mathrm{B}+)$.

Hasil penilaian rata-rata siswa dalam pembelajaran tematik terpadu yang memenuhi kriteria ketuntasan minimal (KKM) pada siklus I pertemuan 1sebanyak 21 siswa dari 36 siswa, dengan persentase ketuntasan siswa $58,3 \%$. Pada siklus I pertemuan 2 meningkat sebanyak 27 siswa dari 36 siswa dengan persentase ketuntasan siswa 75\%. Kemudian meningkat pada siklus II sebanyak 32 siswa tuntas dari 36 siswa, dengan persentase ketuntasan siswa 88,9\%. Dengan demikian, model Discovery Learning dapat meningkatkan proses pembelajaran tematik terpadu.

\section{DAFTAR PUSTAKA}

Faisal. 2014. Sukses Mengawal Kurikulum 2013 di SD. Yogyakarta: Diandra Creative

Kemendikbud. 2014. Materi Pelatihan Guru Implementasi Kurikulum 2013 Tahun 2014. Jakarta: Kemendikbud

Majid, Abdul. 2014. Pembelajaran Tematik Terpadu. Bandung: PT. Remaja Rosdakarya

Mulyasa. 2014. Pengembangan dan Implementasi Kurikulum 2013. Bandung: PT. Remaja Rosdakarya

Rusman. 2011. Model-model Pembelajaran. Jakarta: Rajagrafindo Persada

Uno, Hamzah B, dkk. 2011. Menjadi Peneliti PTK yang profesional. Bumi Aksara: Jakarta 